\title{
Do Muslim CEOs and Muslim stakeholders prefer Islamic debt financing?
}

\author{
Rayenda Khresna Brahmana ${ }^{\text {a }}$, Hui Wei You ${ }^{\text {a,b,* }}$ \\ ${ }^{\text {a }}$ Faculty of Economics and Business, Universiti Malaysia Sarawak, Kota Samarahan 94300, Sarawak, Malaysia \\ ${ }^{\mathrm{b}}$ School of Management, Zhejiang University, Hangzhou 310058, China
}

\section{A R T I C L E I N F O}

\section{Keywords:}

Muslim CEO

Muslim stakeholders

Islamic debt financing

\begin{abstract}
A B S T R A C T
This study examines the relationship between religiosity and Islamic debt financing based on Malaysian non-financial listed firms from 2012 to 2018. We find that Muslim CEOs allocate more Islamic financing in their debt financing compared to non-Muslim CEOs, which support the upper echelons theory. However, we find that the sociological pressure from Muslim Stakeholders display no significant effect on Islamic financing. Interestingly, we further find that Islamic debt financing will incline no matter whether the Muslim population is high or low if the CEO was a Muslim. This implies that our findings support the upper echelon theory, but not the stakeholder orientation theory.
\end{abstract}

\section{Introduction}

With the emergence of Islamic financing products, the Islamic finance literature has extensively examined the superiority of shariacompliant finance product in terms of lower credits risk (How, Karim, \& Verhoeven, 2005), lower investment risk (Halim, How, et al., 2019) better liquidity (Halim, Kabir Hassan, et al., 2019; Siddiqui, 2008), and prudent lending (Kayed \& Hassan, 2011). Empirical findings address Islamic financing as the prescription for business risk mitigation (i.e., Kayed \& Hassan, 2011), financial crises (i.e., Ahmed, 2010; Kayed \& Hassan, 2011), and inducing competitiveness (i.e., Mulla, 2017) with the tenet of the ethical and prudent business model focusing on financial sustainability (Ahmed, Kabir Hassan, \& Rayfield, 2018; Aliyu, Hassan, Mohd Yusof, \& Naiimi, 2017; Paltrinieri, Khan, \& Bahoo, 2019). Despite such a straightforward argument regarding the superiority of Islamic financing, research about the Muslim preference towards the use of Islamic financing is still lacking amid several attempts from Hilary and Hui (2009), Baxamusa and Jalal (2014), and Adhikari and Agrawal (2016). The anecdotal evidence strengthens our argument by revealing that Islamic financial product is less attentive in Islamic countries like Saudi Arabia, Pakistan, Malaysia, or Indonesia. Therefore, do Muslims prefer Islamic debt financing?

One of the reasons for the lack of using Islamic financing may be related to the personal value of the organization's CEOs and the stakeholders. Consistent with upper echelons theory and stakeholder orientation theory, which suggest that CEO and stakeholder's characteristics influence how they respond to financial decision making (Hambrick \& Mason, 1984; Hilary \& Hui, 2009), the use of Islamic debt financing likely depends on the value of CEO and stakeholders (Halim, Kabir Hassan, et al., 2019; Oseni and Kabir Hassan, 2015). Given the importance of the value of CEO and stakeholders to motivate them to act in the best interest of shareholders, better understanding how intimate value such as religion influence the use of Islamic debt financing is critical to economics and finance

\footnotetext{
* Corresponding author at: Faculty of Economics and Business, Universiti Malaysia Sarawak, Kota Samarahan 94300, Sarawak, Malaysia.

E-mail addresses: 11920065@zju.edu.cn, 17010156@siswa.unimas.my (H.W. You).
} 